\title{
Conformity of bacterial growth in sputum and contamination free endobronchial samples in patients with cystic fibrosis
}

\author{
HANS GILLJAM, ANNA-STINA MALMBORG, BIRGITTA STRANDVIK \\ From the Departments of Lung Medicine, Clinical Microbiology, and Paediatrics, Karolinska Institutet, \\ Huddinge University Hospital, Stockholm, Sweden
}

ABSTRACT The use of sputum cultures to guide the antimicrobial treatment of patients with cystic fibrosis has been questioned. Bacterial growth and antibiotic susceptibility patterns of 33 culture pairs from sputum and contamination free endobronchial swabs from 14 patients with cystic fibrosis were compared. As expected, Pseudomonas aeruginosa of the mucoid and non-mucoid type, Staphylococcus aureus, and Haemophilus influenzae were the organisms most frequently found. Absolute or good agreement was found in $73 \%$ of the culture pairs. The accuracy of the sputum cultures improved with the duration of antimicrobial treatment. The extra information gained from the endobronchial culture did not change the antimicrobial strategy from that based on the sputum culture alone. It is concluded that sputum cultures provide accurate information about the bacterial colonisation of the lower respiratory tract in patients with cystic fibrosis and therefore can be trusted both at onset of treatment and during the entire treatment period.

Factors as yet unknown make the bronchial tree of patients with cystic fibrosis prone to become colonised by bacteria and in particular with Staphylococcus aureus and Pseudomonas aeruginosa. The validity of sputum cultures in the evaluation of pulmonary infections has traditionally been debated and accordingly the usefulness of sputum cultures in cystic fibrosis has been questioned. ${ }^{12}$ With the aid of a fibreoptic bronchoscope and a plugged telescoping catheter brush, contamination free bacteriological samples can be obtained without surgical intervention. This study compares sputum with bronchial cultures to test the validity of sputum cultures in cystic fibrosis.

\section{Methods}

\section{PATIENTS}

We studied 14 patients (seven male, seven female) with typical histories and clinical signs of cystic fibrosis as well as pathological sweat test results (sweat chloride concentrations $>80 \mathrm{mmol} / \mathrm{l}$ ). The

\footnotetext{
Address for reprint requests: $\mathrm{Dr}$ H Gilljam, Lungmedicinska
} kliniken, Huddinge sjukhus, S-141 86 Huddinge, Sweden.

Accepted 21 January 1986 mean age was 26 (range 17-65) years. Thirty three investigations were made during a two year period and there were one to 10 cultures for each individual. Most patients were admitted to hospital and received antimicrobial treatment intravenously. The most frequently used combination was of an aminoglycoside and a cephalosporin (see tables), but combinations with isoxazolylpenicillin or ureidopenicillin were also used. Some patients were having antibiotics orally or by inhalation at the time of investigation and some had had no antibiotic treatment at all. The clinical condition of the patients was assessed by the Shwachman score. ${ }^{3}$ All patients had the same basic treatment with pancreatic enzyme supplementation (except patient 9), orally administered fat soluble vitamins in water dispersion, bromhexine, inhalation treatment with $N$-acetylcysteine and terbutaline, and chest physiotherapy.

\section{EXPERIMENTAL DESIGN}

A fresh sputum sample was collected immediately before fibreoptic bronchoscopy, which was performed with local anaesthesia. Phenobarbitone $50-100 \mathrm{mg}$, oxicon chloride 5-10 mg subcutaneously, or diazepam $5 \mathrm{mg}$ intramuscularly (or a combination) were used as premedication. The patients inhaled $12 \mathrm{ml}$ lignocaine $(40 \mathrm{mg} / \mathrm{ml})$ via an ultrasonic nebu- 
Table 1 Bacterial growth in sputum and bronchial brush samples in cystic fibrosis patients without antimicrobial treatment, with less than days of systemic treatment or with short term oral and/or inhaled antibiotics

\begin{tabular}{|c|c|c|c|c|c|c|c|c|c|}
\hline \multirow{2}{*}{$\begin{array}{l}\text { Patient } \\
\text { No }\end{array}$} & \multirow{2}{*}{$\begin{array}{l}\text { Culture } \\
\text { No }\end{array}$} & \multirow[t]{2}{*}{ Age/sex } & \multirow[t]{2}{*}{ Score } & \multicolumn{2}{|c|}{ Antibiotic given at time } & \multicolumn{4}{|l|}{ Organisms isolated } \\
\hline & & & & Drug & Days & Sputum & Amount* & $L E / S E C$ & Bronchus \\
\hline 4 & $4: 2$ & $22 / \mathbf{M}$ & 83 & - & - & $\begin{array}{l}\text { Staph aureus } \\
\text { Pseudomonas sp mucoid }\end{array}$ & $\begin{array}{l}++ \\
++\end{array}$ & ND & $\begin{array}{l}\text { Staph aureus } \\
\text { Pseudomonas sp } \\
\text { non-mucoid }\end{array}$ \\
\hline 5 & $5: 1$ & $46 / \mathrm{F}$ & 95 & - & 二 & Pseudomonas sp mucoid (1) & ++ & $>5$ & Pseudomonas sp mucoid (2) \\
\hline 7 & $7: 1$ & $19 / \mathrm{F}$ & 39 & - & & $\begin{array}{l}P \text { aeruginosa mucoid } \\
P \text { aeruginosa non-mucoid } \\
\text { H parainfluenzae }\end{array}$ & $\begin{array}{l}++ \\
+t \\
+t\end{array}$ & & $\begin{array}{l}\text { P aeruginosa mucoid } \\
\alpha \text { Streptococci } \\
\gamma \text { Streptococci }\end{array}$ \\
\hline 8 & $8: 1$ & $21 / \mathrm{F}$ & 85 & - & - & $\begin{array}{l}\text { Pseudomonas sp mucoid } \\
\text { Pseudomonas sp mucoid } \\
\text { Pseudomonas aeruginosa } \\
\text { non-mucoid }\end{array}$ & $\begin{array}{l}+++ \\
+++ \\
+++\end{array}$ & $>5$ & $\begin{array}{l}\text { Pseudomonas sp mucoid } \\
\alpha \text { Haemolytic streptococci }\end{array}$ \\
\hline 8 & $8: 2$ & $21 / \mathrm{F}$ & 83 & $\begin{array}{l}\text { Tobramycin } \\
\text { inhaled } \\
\text { Pivampicillin } \\
\text { orally }\end{array}$ & 7 & $\begin{array}{l}\text { P aeruginosa mucoid } \\
P \text { aeruginosa non-mucoid }\end{array}$ & $\begin{array}{l}++ \\
++\end{array}$ & $>5$ & $P$ aeruginosa mucoid \\
\hline 9 & 9:1 & $65 / M$ & 67 & - & - & $\begin{array}{l}\text { H influenzae (?) } \\
\beta \text { Haemolytic streptococci C } \\
E \text { coli non-mucoid }\end{array}$ & $\begin{array}{l}++ \\
++ \\
+ \\
++\end{array}$ & ND & $\begin{array}{l}\text { H influenzae (?) } \\
\beta \text { Haemolytic streptococci C }\end{array}$ \\
\hline 9 & $9: 2$ & $65 / M$ & 65 & - & - & $\begin{array}{l}\text { Staph aureus } \\
\text { E coli } \text { non-mucoid }\end{array}$ & $\begin{array}{l}+ \\
++\end{array}$ & $>5$ & $\begin{array}{l}\text { Staph aureus } \\
\text { Pseudomonas sp non-mucoic } \\
\text { Diphtheroids }\end{array}$ \\
\hline 11 & $11: 2$ & $27 / \mathrm{F}$ & 55 & $\begin{array}{l}\text { Flucloxacillin } \\
\text { orally }\end{array}$ & 6 & E coli mucoid & ++ & ND & E coli mucoid \\
\hline 11 & $11: 4$ & $27 / \mathrm{F}$ & 54 & $\begin{array}{l}\text { Cotrimoxazole } \\
\text { orally }\end{array}$ & 1 & $\begin{array}{l}\text { P maltophilia } \\
\text { E coli mucoid } \\
P \text { aeruginosa non-mucoid }\end{array}$ & $\begin{array}{l}++ \\
++ \\
+\end{array}$ & ND & $\begin{array}{l}P \text { maltophilia } \\
\text { E coli mucoid }\end{array}$ \\
\hline 11 & $11: 5$ & $27 / \mathrm{F}$ & 55 & - & - & $\begin{array}{l}\text { P aeruginosa non-mucoid } \\
\text { P aeruginosa mucoid } \\
\text { Pseudomonas sp non-mucoid } \\
\text { E coli } \text { mucoid }\end{array}$ & $\begin{array}{l}+++ \\
+++ \\
+++ \\
+++\end{array}$ & $>5$ & $\begin{array}{l}P \text { aeruginosa non-mucoid } \\
P \text { aeruginosa mucoid } \\
P \text { seudomonas sp non-mucoid } \\
E \text { coli } \text { mucoid }\end{array}$ \\
\hline 12 & $12: 1$ & $24 / F$ & 90 & - & - & Staph aureus & ++ & $>5$ & Staph aureus \\
\hline 13 & $13: 6$ & 20/M & 46 & & - & $\begin{array}{l}\text { P aeruginosa mucoid } \\
\text { H parainfluenzae }\end{array}$ & $\begin{array}{l}+++ \\
+\end{array}$ & & $\begin{array}{l}P \text { aeruginosa mucoid } \\
P \text { aeruginosa non-mucoid }\end{array}$ \\
\hline 13 & $13: 9$ & $20 / \mathrm{M}$ & 51 & $\begin{array}{l}\text { Tobramycin } \\
\text { inhaled }\end{array}$ & 30 & $\begin{array}{l}P \text { aeruginosa mucoid } \\
\beta \text { Haemolytic streptococci C }\end{array}$ & $\begin{array}{l}+++ \\
+++\end{array}$ & $>5$ & $P$ aeruginosa mucoid \\
\hline 13 & $13: 10$ & $20 / \mathrm{M}$ & 48 & - & - & $\begin{array}{l}P \text { aeruginosa mucoid } \\
P \text { aeruginosa non-mucoid }\end{array}$ & $\begin{array}{l}++ \\
++\end{array}$ & ND & $\begin{array}{l}\text { P aeruginosa mucoid } \\
\text { Pseudomonas sp non-mucoid } \\
\text { Gram negative rods }\end{array}$ \\
\hline
\end{tabular}

LE/SEC-microscopic evaluation of sputum representativity; ND-not done. *Amount-arbitrary estimation of bacteria present in sputum ( +++ O heavy, $++=$ moderate, $+=$ sparse growth). A suffix in brackets after the name of a strain indicates that the strains were not identical in sputum afed bronchus.

liser (DeVilbiss 35A, DeVilbiss Company, Somerset, Pennsylvania) and the endoscope was inserted by the nasal route. With the instrument positioned in the left main bronchus, a plugged telescoping catheter brush (Medi-Tech, BFW/1.0/70/90; Medi-Tech Inc, Watertown, Massachusetts) was inserted through the suction channel of the endoscope and the tip advanced $2-4 \mathrm{~cm}$ beyond the instrument, where the inner catheter with the brush was advanced further and the polyethylene glycol plug was dislodged. The inner catheter was moved forward and then the brush was advanced distally and the brushing performed. The brush was thereafter withdrawn into the inner catheter and the latter into the outer sheath, and the entire system withdrawn from the bronchoscope. The distal portion of the outer and inner catheters was then severed with sterile scissors and discarded. The inner catheter was advanced a few centimeters and the brush moved forward to protrude, after which it was severed with sterile scissors and immediately placed in sterile saline.

\section{BACTERIOLOGY}

The sputum samples were placed in an ordinary tea strainer and washed with tap water as described by Bartlett and Finegold. ${ }^{4}$ Thereafter the samples were Gram stained and examined microscopically to obtain the ratio of leucocytes to squamous epithelial cells. Smears with ratios of leucocytes to epithelial cells of more than 5 were classified as purulent and representative of sputum, as suggested by Kalin et al. ${ }^{5}$

Sputum cultures were performed in a semiquantitative manner. ${ }^{4}$ The specimens were homogenised with dithiothreitol (Sputolysine, Calbiochem), diluted $1 / 100$, and spread by the use of disposable standardised plastic loops containing $10 \mu \mathrm{l}$ on to 
Table 2 Bacterial growth in sputum and bronchial brush samples in patients with cystic fibrosis with 2-13 days of systemic antibiotic treatment

\begin{tabular}{|c|c|c|c|c|c|c|c|c|c|}
\hline \multirow{2}{*}{$\begin{array}{l}\text { Patient } \\
\text { No }\end{array}$} & \multirow{2}{*}{$\begin{array}{l}\text { Culture } \\
\text { No }\end{array}$} & \multirow[t]{2}{*}{ Age/sex } & \multirow[t]{2}{*}{ Score } & \multicolumn{2}{|c|}{ Antibiotic given at time } & \multicolumn{4}{|l|}{ Organisms isolated } \\
\hline & & & & $\overline{\text { Drug* }}$ & $\overline{\text { Days }}$ & Sputum & Amount & $L E / S E C$ & Bronchus \\
\hline 1 & $1: 2$ & $21 / \mathrm{M}$ & 90 & $\begin{array}{l}\text { Ceftazidime } \\
\text { Tobramycin }\end{array}$ & 12 & Normal sputum flora & & $>5$ & No growth \\
\hline 2 & $2: 1$ & $17 / \mathrm{M}$ & 88 & $\begin{array}{l}\text { Cefsulodin } \\
\text { Tobramycin }\end{array}$ & 8 & $P$ aeruginosa mucoid & $+t+$ & ND & $P$ aeruginosa mucoid \\
\hline 3 & $3: 1$ & $21 / F$ & 65 & Cloxacillin & 11 & Staph aureus & + & ND & No growth \\
\hline 4 & $4: 1$ & $22 / \mathrm{M}$ & 83 & Netilmicin & 3 & Staph aureus & + & ND & Staph aureus \\
\hline 4 & $4: 3$ & $22 / \mathrm{M}$ & 80 & Ceftazidime & 7 & Staph aureus & + & $>5$ & No growth \\
\hline 13 & $13: 1$ & $20 / \mathrm{M}$ & 46 & Tobramycin & 10 & $\begin{array}{l}P \text { aeruginosa non-mucoid } \\
P \text { seudomonas sp mucoid }\end{array}$ & $\begin{array}{l}+t+ \\
+\end{array}$ & ND & $P$ aeruginosa non-mucoid \\
\hline 13 & $13: 3$ & $20 / \mathrm{M}$ & 44 & $\begin{array}{l}\text { Ceftazidime } \\
\text { Tobramycin }\end{array}$ & 6 & $\begin{array}{l}P \text { aeruginosa non-mucoid } \\
P \text { aeruginosa mucoid }\end{array}$ & $\begin{array}{l}+t+ \\
++\end{array}$ & $>5$ & $P$ aeruginosa non-mucoid \\
\hline 13 & $13: 4$ & $20 / \mathrm{M}$ & 46 & $\begin{array}{l}\text { Tobramycin } \\
\text { Piperacillin }\end{array}$ & 7 & $\begin{array}{l}P \text { aeruginosa non-mucoid } \\
\text { Pseudomonas } \mathrm{sp} \text { mucoid }\end{array}$ & $\begin{array}{l}+t+ \\
++t\end{array}$ & $>5$ & Enterobacter species \\
\hline 13 & 13:7 & $21 / \mathrm{M}$ & 48 & $\begin{array}{l}\text { Ceftazidime } \\
\text { Tobramycin }\end{array}$ & 6 & $\begin{array}{l}P \text { aeruginosa mucoid (1) } \\
P \text { aeruginosa mucoid (2) } \\
P \text { aeruginosa non-mucoid }\end{array}$ & $\begin{array}{l}+t+ \\
++t \\
++t\end{array}$ & $>5$ & $\begin{array}{l}P \text { aeruginosa mucoid (1) } \\
\text { Pseudomonas sp mucoid } \\
P \text { fluorescens }\end{array}$ \\
\hline 13 & $13: 8$ & $21 / \mathrm{M}$ & 46 & $\begin{array}{l}\text { Ceftazidime } \\
\text { Tobramycin }\end{array}$ & 7 & $\begin{array}{l}\text { Paeruginosa mucoid } \\
\text { Pseudomonas sp mucoid } \\
\beta \text {-Haemolytic streptococci gr C }\end{array}$ & $\begin{array}{l}++t \\
++t \\
+++\end{array}$ & $>5$ & $\begin{array}{l}P \text { aeruginosa mucoid } \\
P \text { aeruginosa non-mucoid } \\
\text { Pseudomonas } \mathrm{sp} \text { non-mucoid }\end{array}$ \\
\hline 14 & $14: 1$ & $19 / \mathrm{M}$ & 90 & $\begin{array}{l}\text { Ceftazidime } \\
\text { Tobramycin }\end{array}$ & 6 & $\begin{array}{l}\text { Staph aureus } \\
P \text { aeruginosa non-mucoid } \\
\text { Enterobacteria }\end{array}$ & $\begin{array}{l}+ \\
+ \\
+\end{array}$ & $>5$ & $\begin{array}{l}\text { Staph aureus } \\
\alpha \text { Haemolytic streptococci }\end{array}$ \\
\hline
\end{tabular}

* Given intravenously in each case.

For abbreviations see table 1 .

Table 3 Bacterial growth in sputum and bronchial brush samples in patients with cystic fibrosis with $\geqslant 14$ days of systemic antibiotic treatment

\begin{tabular}{|c|c|c|c|c|c|c|c|c|c|}
\hline \multirow{2}{*}{$\begin{array}{l}\text { Patient } \\
\text { No }\end{array}$} & \multirow{2}{*}{$\begin{array}{l}\text { Culture } \\
\text { No }\end{array}$} & \multirow[t]{2}{*}{ Age/sex } & \multirow[t]{2}{*}{ Score } & \multicolumn{2}{|c|}{ Antibiotic given at time } & \multicolumn{4}{|l|}{ Organisms isolated } \\
\hline & & & & Drug* & $\overline{\text { Days }}$ & Sputum & Amount & $L E / S E C$ & Bronchus \\
\hline 1 & $1: 1$ & $21 / \mathrm{M}$ & 88 & $\begin{array}{l}\text { Cloxacillin } \\
\text { Netilmicin }\end{array}$ & 14 & No growth & & ND & No growth \\
\hline 3 & $3: 2$ & $21 / F$ & 83 & $\begin{array}{l}\text { Cloxacillin } \\
\text { Piperacillin }\end{array}$ & 14 & $\begin{array}{l}\text { Staph aureus } \\
\text { H infuenzae }\end{array}$ & + & $>5$ & Staph aureus \\
\hline 6 & $6: 1$ & $19 / \mathrm{F}$ & 41 & $\begin{array}{l}\text { Cefsulodin } \\
\text { Netilmicin }\end{array}$ & 14 & $P$ maltophilia & ++ & ND & No growth \\
\hline 10 & $10: 1$ & $17 / \mathrm{M}$ & 65 & $\begin{array}{l}\text { Cloxacillin } \\
\text { Netilmicin }\end{array}$ & 14 & Staph aureus & + & ND & Staph aureus \\
\hline 11 & $11: 1$ & $27 / F$ & 55 & $\begin{array}{l}\text { Ceftazidime } \\
\text { Tobramycin }\end{array}$ & 14 & $\begin{array}{l}P \text { maltophilia } \\
E \text { coli mucoid }\end{array}$ & $\stackrel{+}{+}$ & ND & $\begin{array}{l}P \text { maltophilia } \\
E \text { coli mucoid }\end{array}$ \\
\hline 11 & $11: 3$ & $27 / \mathbf{F}$ & 49 & Ceftazidime & 14 & $\begin{array}{l}\text { P maltophilia } \\
\text { E coli mucoid }\end{array}$ & $\begin{array}{l}+++ \\
+++\end{array}$ & ND & $\begin{array}{l}P \text { maltophilia } \\
\text { E coli mucoid }\end{array}$ \\
\hline 13 & $13: 2$ & $20 / \mathrm{M}$ & 52 & Ceftazidime & 17 & $\begin{array}{l}P \text { aeruginosa non-mucoid } \\
P \text { aeruginosa mucoid }\end{array}$ & $\begin{array}{l}t+t \\
++t\end{array}$ & $>5$ & $P$ aeruginosa non-mucoid \\
\hline 13 & $13: 5$ & $20 / \mathrm{M}$ & 55 & $\begin{array}{l}\text { Ceftazidime } \\
\text { Tobramycin }\end{array}$ & 35 & $\begin{array}{l}P \text { aeruginosa non-mucoid } \\
P \text { aeruginosa mucoid }\end{array}$ & $\begin{array}{l}++ \\
+++\end{array}$ & $>5$ & $\begin{array}{l}P \text { aeruginosa non-mucoid } \\
P \text { aeruginosa mucoid }\end{array}$ \\
\hline
\end{tabular}

* Given intravenously in each case.

For abbreviations see table 1 .

Table 4 Conformity of bacterial growth in sputum and samples from major bronchi in patients with cystic fibrosis

\begin{tabular}{llll}
\hline & \multicolumn{2}{c}{ Bacteria present in } & \\
\cline { 2 - 4 } Bacteria & Both cultures & Only sputum & Only bronchus \\
\hline Staph aureus & 7 & 2 & - \\
H influenzae & 2 & 3 & - \\
H parainfluenzae & - & 2 & - \\
E coli non-mucoid & - & - & - \\
E coli mucoid & 1 & 5 & 1 \\
Pseudomonas sp non-mucoid & 2 & 8 & 2 \\
Pseudomonas sp mucoid & 5 & 3 & - \\
$P$ aeruginosa non-mucoid & 10 & 1 & 1 \\
$P$ aeruginosa mucoid & - & - & - \\
$P$ maltophilia & - & & \\
$P$ fluorescens & & & \\
\hline
\end{tabular}


plates with the following six media: (1) Blood agar with $5 \%$ horse blood for isolation of $S$ aureus. (2) Pseudomonas isolation agar (Difco) for identification of Pseudomonas species. (3) CLED agar (lab m) for isolation of other Gram negative bacilli. (Plates 1-3 were incubated in $37^{\circ} \mathrm{C}$ aerobically for 48 hours.) (4) Blood agar with $5 \%$ sheep blood and gentian violet $0.01 \%$ for the selective isolation of $\beta$ haemolytic streptococci and pneumococci. (5) Haemin-bacitracin agar with a $\mathrm{V}$ factor disc placed on the agar for the selective isolation of Haemophilus species according to Roberts and Cole. ${ }^{6}$ (Plates 4 and 5 were incubated anaerobically for 24 hours.) (6) Haematin agar for identification of all bacteria. (This plate was incubated in $37^{\circ}$ in $5 \%$ carbon dioxide for 48 hours).

The bronchial brushes were transferred to tubes containing dextrose broth and incubated at $37^{\circ} \mathrm{C}$. When there was visible growth, microscopy was performed and subcultures were made on the plates used for the sputum samples except for the haeminbacitracin plate. Two millilitres of the liquid were inoculated into a bottle with biphasic medium (brain heart infusion agar and meat infusion broth, Biotest Bio-Hospital AB, Sweden). The bottle contained nitrogen. Subcultures were made from the bottle if there was visible growth. The method of cultivation of the bronchial brushes did not allow quantification of the growth.

The isolated bacteria were identified according to standard techniques. ${ }^{7}$ Normal pharyngeal flora cultured in sputum were not recorded, whereas all isolates in the bronchial secretion were. Antibiotic sensitivity was determined by the ICS method ${ }^{8}$ with paper discs (AB Biodisk, Sweden).

\section{Results}

Pseudomonas aeruginosa and other species in mucoid and non-mucoid forms were found in eight of the 14 patients in sputum and in bronchial secretions. Staphylococcus aureus was found in six patients in both sputum and bronchial cultures. Pseudomonas maltophilia was found in cultures of both origins in four patients. Escherichia coli, Haemophilus influenzae, $H$ parainfluenzae, and streptococci were less frequently found. No anaerobic bacteria were isolated.

Table 1 shows the results in patients without antibiotic treatment, with less than two days of systemic treatment or with short periods of oral or inhaled antibiotics or both; absolute agreement between sputum and bronchial cultures was seen in only three of the 14 investigations. Ten culture pairs had one identical strain, two pairs had two identical strains, and one pair had four identical strains. In this group of patients Staph aureus was always present in the bronchus when found in sputum and vice versa.
Seven of the 10 strains of mucoid $P$ aeruginosa found in sputum were also recovered from the bronchus, whereas only three of the eight non-mucoid strains of $P$ aeruginosa found in sputum were isolated in the bronchus. On the other hand, three non-mucoid and one mucoid strain of $P$ aeruginosa were found only in the bronchus. One patient who was colonised with $P$ maltophilia showed growth in both cultures. A mucoid $E$ coli was isolated on three occasions in both sputum and bronchus in the same patient. Strains of non-mucoid $E$ coli, $H$ parainfluenzae, and $\beta$ haemolytic streptococci group $\mathrm{C}$ were more often seen in sputum than in the bronchi. Small numbers of different bacteria typical of normal mouth flora were occasionally found in the bronchi. In patients who had had 2-13 days of systemic antibiotic treatment before the investigation (table 2), absolute agreement was seen in three of the 11 investigations. Five culture pairs had one identical strain. One patient had normal sputum flora and no growth was observed in the bronchus. Staph aureus was isolated in sputum on four occasions but only twice in the bronchus. Three of the eight mucoid strains of $P$ aeruginosa found in sputum were simultaneously found in the bronchus and only two of the five non-mucoid strains of the bacterium seen in sputum were found in the corresponding bronchial culture (in one patient). In the bronchial cultures one strain of $\alpha$ streptococci and one non-mucoid $P$ aeruginosa strain were detected that could not be isolated from sputum.

Patients treated for 14 days or more (table 3) showed absolute agreement between cultures in six of the eight investigations, while in one culture pair only one strain was identical. Only one strain each of $P$ aeruginosa and $P$ maltophilia found in sputum could not be detected in the bronchial cultures. The comparisons made for all patients are summarised in table 4.

In patients whose specimens were cultured on several occasions over an extended period of time (Nos 11 and 13) the same bacteria appeared repeatedly. When the growth pattern changed the change was often a definitive one that could be confirmed in subsequent cultures. Interestingly, when in one patient (No 13) a mucoid $P$ aeruginosa emerged during the study period, it was first cultured from sputum and not until nine months later did the same strain appear in the bronchial secretions.

When patients were classified on clinical criteria into those who were more and less ill, agreement between the culture pairs was similar in the two groups.

\section{Discussion}

Our data support studies by Høiby and others ${ }^{9} 10$ 
showing that $P$ aeruginosa, Staph aureus, and $H$ influenzae are the most frequently encountered bacterial species in sputum from patients with cystic fibrosis. Beaudry and coworkers, however, expressed doubts about the predictive value of sputum cultures in cystic fibrosis and asked for studies on patients with mild and moderate disease and also pleaded for a more complete microbial evaluation correlating sputum cultures with cultures from the lower respiratory tract. ${ }^{2}$ Results of an early study by Baran and Cordier showed that cultures obtained by transtracheal puncture are consistent with sputum cultures in $85 \%$ of the culture pairs. ${ }^{11}$ In a recent paper Thomassen et al compared sputum cultures with cultured lung tissue obtained at thoracotomy or cultured lung aspirates or both. ${ }^{12}$ In 17 adolescent and adult patients in a relatively poor condition they found that sputum cultures could accurately predict the bacteria actually found in lung tissue in $73 \%$ of all investigations.

In our study, in which most patients were in good clinical condition, absolute or good agreement between bronchial and sputum cultures was also seen in $73 \%$ of all investigations. Most of the remaining culture pairs were identical as regards the most important pathogen or pathogens. The total agreement of bacterial growth between culture pairs increases steadily with the duration of treatment. Evidently, most bacteria succumb during broad spectrum antibiotic regimens giving measurable serum and sputum concentrations of antibiotics. ${ }^{13-15}$ Like Hodson et al, ${ }^{16}$ we have found oral or inhaled antibiotics to be less effective than parenteral administration. Patients having oral or inhaled antibiotics showed patterns of bacterial growth similar to those of patients having no treatment or less than two days of systemic antimicrobial treatment.

On four occasions one or several strains of pseudomonas were found in the bronchi, supporting the observation by Thomassen et al that patients with cystic fibrosis are often colonised with a mixture of different pseudomonas strains. ${ }^{17}$ On 12 occasions individual strains of pseudomonas were found in sputum that could not be detected in the bronchus. According to a recent report by Lindemann et al, the oral cavity is an important reservoir for pseudomonas in cystic fibrosis. ${ }^{18}$ Thus two patients in whom the culture pairs could be monitored over an extended period of time were of particular interest. In one (patient 13) a mucoid strain of $P$ aeruginosa that was later to become permanent first appeared in the sputum culture. A similar development could be seen in patient 11 for a non-mucoid strain of the same bacterium. Possibly therefore factors that promote growth of pseudomonas-mucoid or non-mucoid-first favour colonisation in the oral cavity. The results indicate that intravenously administered antibiotics influence the bacterial flora mainly by eradicating the upper respiratory microbial colonisers, giving an almost complete agreement between the pathogens typical of cystic fibrosis in sputum and bronchus.

\section{References}

1 Marks MI. The pathogenesis and treatment of pulmonary infections in patients with cystic fibrosis. J Pediatr 1981;98:173-9.

2 Beaudry PH, Marks MI, McDougall D, Diamond K, Rangel $\mathbf{R}$. Is anti-Pseudomonas therapy warranted in acute respiratory exacerbations in children with cystic fibrosis? J Pediatr 1980;97:144-7.

3 Shwachman H, Kulczycki L. A report of one hundred and five patients with cystic fibrosis of the pancreas studied over a five to fourteen year period. Am J Dis Child 1958;96:6-15.

4 Bartlett JG, Finegold SA. Bacteriology of expectorated sputum with quantitative culture and wash technique compared to tracheal aspirates. Am Rev Respir Dis 1978;117:1019-27.

5 Kalin A, Lindberg AA, Tunevall G. Etiological diagnosis of bacterial pneumonia by Gram stain and quantitative culture of expectorates. Scand J Infect Dis 1983;15:153-60.

6 Roberts D, Cole P. Use of selective media in bacteriological investigation of patients with chronic suppurative respiratory infection. Lancet 1980;i:796-7.

7 Cowan ST, Steel KJ. Manual for the identification of medical bacteria. 2nd ed. London: Cambridge University Press, 1974.

8 Ericsson HA, Sherris JC. Antibiotic sensitivity testing. Report of an international collaborative study. Acta Pathol Microbiol Scand 1971;2 (suppl 7):1-90.

9 Høiby N. Microbiology of lung infections in cystic fibrosis patients. Acta Paediatr Scand 1982; suppl 301:33-54.

10 Mearns MB. Natural history of pulmonary infection in cystic fibrosis. In: Sturgess JM ed., Perspectives in cystic fibrosis. Proceedings of the 8th international cystic fibrosis congress. Toronto: Imperial Press, 1980:325-34.

11 Baran D, Cordier N. Usefulness of transtracheal puncture in the bacteriological diagnosis of lung infections in children. Helv Paediatr Acta 1973;28:391-9.

12 Thomassen MJ, Klinger JD, Badger SJ, van Hackeren DW, Stern RC. Cultures of thoracotomy specimens confirm usefulness of sputum cultures in cystic fibrosis. J Pediatr 1984;104:352-6.

13 Malmborg A-S, Alfredsson H, Kusoffsky E, Strandvik B. Azlocillin and gentamicin in respiratory tract infections with Pseudomonas aeruginosa in patients with cystic fibrosis. Scand J Infect Dis 1981; suppl 29:64-9.

14 Strandvik B, Malmborg A-S, Alfredsson H. Cefsulodin in the treatment of Pseudomonas aeruginosa infections in patients with cystic fibrosis. Chemioterapia 1983;2 (suppl 5):276-7.

15 Strandvik B, Malmborg A-S, Alfredsson H, Ericsson A. 
Clinical results and pharmacokinetics of ceftazidime treatment in patients with cystic fibrosis. $J$ Antimicrob Chemother 1983;12 (suppl A):283-7.

16 Hodson ME, Penketh ARL, Batten JC. Aerosol carbenicillin and gentamicin treatment of Pseudomonas aeruginosa infection in patients with cystic fibrosis. Lancet 1981;ii:1137-9.

17 Thomassen MJ, Demko CA, Boxerbaum B, Stern RC,
Kuchenbrod PJ. Multiple isolates of Pseudomonas aeruginosa with differing antimicrobial susceptibility patterns from patients with cystic fibrosis. $J$ Infect Dis 1979;140:873-80.

18 Lindemann RA, Newman MG, Kaufman AK, Le TV. Oral colonization and susceptibility testing of Pseudomonas aeruginosa oral isolates from cystic fibrosis patients. J Dent Res 1985;64:54-7. 